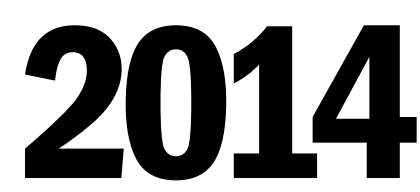

volume 11 | issue 1

an open access journal for architectural research

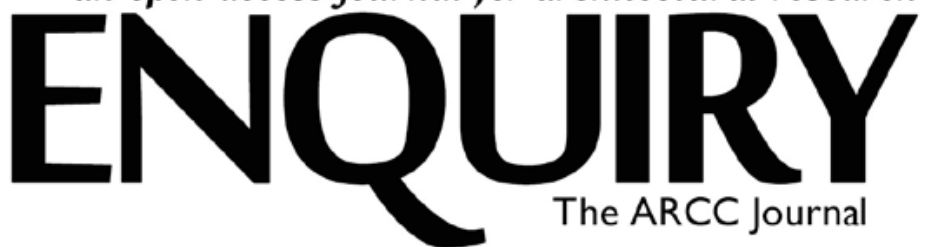

\title{
SUSTAINABILITY AND THE ARCHITECTURAL HISTORY SURVEY
}

\author{
Vandana Baweja
}

\begin{abstract}
Architecture and urbanism have engaged sustainability as an actionoriented objective through the practice of green design and sustainable urbanism, which have several iterations. Architectural history has yet to produce a significant body of work in response to environmental discourses that are currently dominated by sustainability. The architectural history survey - when taught from an environmental history perspective - can serve the purpose of understanding not just sustainability, but the relationship of architecture and urbanism to the environment through history. I address the question, how can sustainability, a 1980 s paradigm, be addressed in the teaching of the architectural history survey that ranges from pre-history to contemporary times? Sustainability is a dominant contemporary paradigm of environmentalism produced through economic development discourses of environmental management. I argue that the architectural history survey can provide opportunities to engage environmental histories in unearthing and disseminating ecological histories of architecture and urbanism. The architectural history survey - when taught from an environmental history perspective - can serve the purpose of understanding the environmental discourses that have informed sustainability historically, across different times and cultures. I propose that teaching architectural history within the larger field of environmental history is one way through which sustainability, as an environmental management paradigm, can be grasped, defined, and
\end{abstract}

\section{Permissions and copyright}

Authors retain copyright and grant the journal right of first publication with the work simultaneously licensed under a Creative Commons Attribution License that allows others to share the work with an acknowledgement of the work's authorship and initial publication in this journal (Atribution-ShareAlike).

Creative Commons Attribution 3.0 Unported (CC BY 3.0)

You are free to: Share - copy and redistribute the material in any medium or format. Adapt - remix, transform, and build upon the material for any purpose, even commercially. The licensor cannot revoke these freedoms as long as you follow the license terms.

Under the following terms: Attribution - You must give appropriate credit, provide a link to the license, and indicate if changes were made. You may do so in any reasonable manner, but not in any way that suggests the licensor endorses you or your use.

No additional restrictions - You may not apply legal terms or technological measures that legally restrict others from doing anything the license permits.

How to cite:

Baweja, Vandana. 2014. "Sustainability and the Architectural History Survey." Enquiry 11 (1): 40-51. critiqued. Environmental history is one of the fastest growing fields of history, and is not a subdiscipline of history but a metadiscipline, given its scope and inclusivity. Writing architectural histories within the metadiscipline of environmental history is emerging as a new way of producing architectural histories. The architectural history survey taught from an environmental history perspective can contribute to an understanding of fundamental concepts about architecture and cities within the environmental discourse and therefore position the idea of sustainability historically.

\section{INTRODUCTION}

Since the 1990s, sustainable development has emerged as the new paradigm of economic growth based on the carrying capacity of the earth. Consequently, the built environment - architecture and urbanism - have been amongst the core sectors of intervention to achieve sustainable development. ${ }^{1}$ In the field of architectural practice, there is a substantial body of scholarship on sustainable architecture as a goal. However, as a discipline architectural history has not yet engaged environmental histories to produce substantial scholarship on how societies have addressed architecture in its ecological context. I argue that the architectural history survey can provide opportunities to engage environmental histories in unearthing and disseminating ecological histories of architecture and urbanism. The architectural history survey - when taught from an environmental history perspective - can serve the purpose of understanding the environmental discourses that have informed sustainability historically, across different times and cultures.

Sustainable development was first defined in the Brundtland Report, titled Our Common Future, as development that "meets the needs of the present without compromising the ability of future generations to meet their own needs." ${ }^{2}$ The Brundtland Report was written from the perspective of the economy, that is, how the deteriorating quality of the environment and diminishing supplies of finite natural resources can be impediments to 
economic growth. The genealogy of the Brundtland Report can be traced to older manifestoes, such as the Club of Rome's The Limits to Growth: a Report for the Club of Rome's Project on the Predicament of Mankind, and E. F. Schumacher's Small is Beautiful: Economics as if People Mattered. ${ }^{3}$ After the Brundtland Report, the Rio Summit generated the next manifesto on sustainability, titled Agenda 21, which laid out clear guidelines for sustainable architecture and settlements. ${ }^{4}$ Subsequently, based on the Brundtland definition, the term "sustainability" entered the public discourse and has had an enduring impact on several disciplines in academia. ${ }^{5}$ Sustainability translates into practices that achieve balance between economic growth and the earth's regenerative and carrying capacity.

There are several definitions of the term "sustainability" and there is no unanimity on what it means. It is an abstract concept that has been overused to include so many goals that the very breadth of its scope has made the term problematic and somewhat inconsequential. ${ }^{6}$ In this paper sustainability is defined as a paradigm of environmental management based on the carrying capacity of the earth. Sustainability began as a goal to achieve sustained economic growth and is being transformed into a discipline. ${ }^{7}$ Architecture and urbanism have engaged sustainability as an action-oriented objective through the practice of green design and sustainable urbanism, which have several iterations. Architectural history has yet to produce a significant body of work in response to environmental discourses that are currently dominated by sustainability. Architectural historians have reflected on the impact of sustainability on the architectural academe, with reservations that the increasing emphasis on sustainability may further marginalize architectural history. ${ }^{8}$ I propose the contrary: the architectural history survey - when taught from an environmental history perspective - can serve the purpose of understanding not just sustainability, but the relationship of architecture and urbanism to the environment through history.

I address the question - how can sustainability, a 1980s paradigm, be addressed in the teaching of the architectural history survey that ranges from pre-history to contemporary times? Sustainability is a dominant contemporary paradigm of environmentalism produced through economic development discourses of environmental management. Primarily based on the limits of resources and minimizing the impact of harmful anthropogenic processes on the planet, sustainability has an intellectual trajectory that intersects with the history of architecture and urbanism. The intellectual origins of sustainability can be traced to several older paradigms of environmentalism that have existed throughout history. Examples include Aristotle's and Pliny's concerns over deforestation and soil erosion; medieval European concerns over deforestation; Venetian anxieties over the depletion of oak and naval grade timber on their mainland territories; the Ming dynasty's concern over Beijing's water pollution and the consequent southward extension of its southern boundary; Mughal notions of the paradise garden, its application in water management and gardening; concerns over atmospheric pollution in England over coal burning in the 1600s; sustained yield (Nachhaltigkeit) German forestry; hygiene and urban pollution problems related to the Industrial Revolution; preservation and conservation movements; environmental concerns in the European colonies; Malthusian theories of the finite resources of the earth; and the modern environmentalist movement which gained significant traction through the work of women like Rachel Carson and Lois Gibbs. By framing sustainability historically through the lens of environmental architectural and urban histories, the idea of sustainability can be grasped. The survey can be a critical forum for examining how architecture and urbanism have made societies sustainable or unsustainable in the past. The architectural history survey, taught within environmental history, can offer the opportunity to understand environmentalisms in relationship to architecture and urbanism through human histories.

I propose that teaching architectural history within the larger field of environmental history is one way through which sustainability, as an environmental management paradigm, can be grasped, defined, and critiqued. Environmental history is one of the fastest growing fields of history, and is not a subdiscipline of history but a metadiscipline, given its scope and inclusivity. Writing architectural histories within the metadiscipline of environmental history is emerging as a new way of producing architectural histories. The architectural history survey taught from an environmental history perspective can contribute to an understanding of fundamental concepts about architecture and cities within the environmental discourse and therefore position the idea of sustainability historically. The architectural history survey could engage with questions such as how architecture and cities have been related to ecological regions, bioregions, and earth systems through histories. In addition, the survey can also provide a framework for understanding ways in which societies have faced environmental stresses, managed their environments, and produced environmental knowledge throughout history. Such an approach would potentially facilitate a more integrated delivery of environmental education in the history of architecture curriculum and the design studio, as is becoming evident in new texts such as P. Tabb and A. S. Deviren's The Greening of Architecture: A Critical History and Survey of Contemporary Sustainable Architecture and Urban Design. ${ }^{9}$ 


\section{THE NEED FOR AN ARCHITECTURAL ENVIRONMENTAL HISTORY SURVEY}

The discipline of architecture has absorbed the discourse of sustainability largely through the fields of building construction technology and environmental technology, all within the larger field of science. The relationship between architectural studio education and sustainability is heavily weighted toward the applied sciences, leaving little room for the discipline of architecture to engage with humanistic questions of sustainability. In the design studio, the environmental problems emphasized in the Brundtland Report - for example, energy consumption and the diminishing reserve of fossil fuels, depletion of natural resources, exponential urban growth, and inadequate housing are seen as design problems. These are addressed by solutiondriven approaches such as Cradle to Cradle, Ecological Design, net zero buildings, and zero-carbon buildings. ${ }^{10}$ These performancebased paradigms operate through empirical measures such as energy consumption, greenhouse gas emissions, resource management, life cycle assessment, indoor air quality control, and waste management. Olgyay and Herdt define green buildings as "examples of applied ecology," where architects treat the construction site as an ecosystem, and the building in an ecological relationship with its site. ${ }^{11}$ Climate change and its metrics - energy consumption and the carbon cycle - dominate green design. A manual of green design titled The Green Studio Handbook: Environmental Strategies for Schematic Design defines the ethical objective of green design thus:

While green design focuses upon reducing the environmental impacts of energy, water, and material usage (including, presumably, carbon emissions), truly informed designs must explicitly reduce the carbon dioxide emissions from buildings. ${ }^{12}$

The definition of green design in terms of the carbon metric links individual buildings directly to global systems such as climate change. Design studios emphasize the problem-solving approach, where design is expected to provide the solution to the built environment's challenges to our survival, namely finite and unequally distributed energy sources, and the limited supply of building materials. A plurality of paradigms such as "eco-technic," "eco-centric," "eco-aesthetic," "eco-cultural," "eco-medical," and "eco-social" are used to locate buildings on the environmentalist spectrum. ${ }^{13}$ However, these applied approaches are often inadequate in addressing the cultural, social, ideological, and ethical aspects of green design. ${ }^{14}$

History and theory of architecture can question how the sustainable design discourse has been constructed and why some paradigms, such as net zero buildings, dominate the discourse in their centrality to state policies related to architecture in the United States and the European Union. Since architecture and urbanism constitute primary areas of intervention in sustainability manifestoes, architectural discourses can question how and why sustainability is defined in terms of carrying capacity and sustained economic growth. An architectural environmental body of knowledge such as the history survey can effectively question the place of architectural design and urban planning in the sustainability discourses.

\section{ENVIRONMENTAL AND ARCHITECTURAL HISTORIES}

As a field of inquiry, environmental history emerged out of the environmental movement of the $1960 \mathrm{~s}$ and $1970 \mathrm{~s} .{ }^{15} \mathrm{~J}$. Donald Hughes defines environmental history as human history through an ecological lens. ${ }^{16}$ Environmental history is an emerging metadiscipline that faces the daunting task of unifying ecological histories, societal formations, histories of technology, and cultural histories into a meta-narrative. ${ }^{17}$ John McNeill has classified environmental history into three broad categories: material histories, cultural and intellectual histories, and political histories. ${ }^{18}$ Architectural and urban histories can be classified as subsets of the metadiscipline of environmental history as material environmental histories, that is, the history of human habitats. To that effect, it would be useful to think of a history of architecture and cities as a history of ecosystems, where the built environment is conceived as a set of ecological relationships. ${ }^{19}$

\section{The Environment in Architecture History Surveys}

Architectural histories, which have their intellectual origins in art history and cultural studies, focus on the socio-cultural processes in the production of architecture and urbanism. The major history of architecture survey textbooks, such as A Global History of Architecture; World Architecture: a Cross-cultural History; A History of Architecture: Settings and Rituals; Buildings across Time: An Introduction to World Architecture; and Architecture, from Prehistory to Postmodernity chronicle how culture and technology determine architecture and urbanism. ${ }^{20}$ These histories emphasize a formal, spatial, technological, and cultural reading of architecture. They construct a narrative that is based on the finest architectural and urban achievements of civilizations, empires, dynasties, nation-states, tribes, and individual architects. As textbooks they constitute effective strategies to meet the curriculum requirements. However, environmental history is not adequately represented in these surveys. The environment is a passive locale on which architecture and cities, as products of human agency, are constructed. ${ }^{21}$ The environment is seen as providing a stable set of deterministic criteria, such as: climate, topography, natural features, and water availability. These texts rely on human agency as a driving force in the making of 
architecture and cities. The role of the environment as an agent in architectural and urban transformations is not emphasized enough.

Within architecture, there is growing scholarship on how to build green buildings, but there are not enough architectural histories written from an environmental perspective to warrant a field of architectural environmental history. The only architectural environmental survey of Modernism is Reyner Banham's The Architecture of the Well-Tempered Environment. Banham's book is written from the perspective of the environmental design of buildings. The emphasis is on how buildings in Western Europe and the United States changed as building services advanced and transitioned to fossil fuel powered electricity. The survey focuses on how architectural technology impacted the spatial configurations of buildings in the fossil fuel age, but not on the impact of a fossil fuel dependent architecture on the environment. There are only a handful of architectural histories that intersect with environmental histories, including P. Anker's From Bauhaus to Ecohouse a History of Ecological Design; M. Murphy's Sick Building Syndrome and the Problem of Uncertainty: Environmental Politics, Technoscience, and Women Workers; David Orr's Design on the Edge: The Making of a High-Performance Building; and P. Tabb and A. S. Deviren's The Greening of Architecture. ${ }^{22}$ They mostly focus on the twentieth century. These histories chronicle the change in architecture and urbanism with the rise of modern environmentalism.

\section{Architecture within Environmental History Surveys}

Environmental history surveys include cities, insofar as city building is one kind of human activity amongst many - such as agriculture, deforestation, hunting, and irrigation - that have transformed the environment. There is very little emphasis on architecture in environmental histories. Given its scale, the city has been established as an enduring unit of analysis in environmental history, as it represents several large scale and complex transformations of the environment. ${ }^{23}$ In the early 1990s, the Worsterian "agroecological" perspective, which focused heavily on agriculture as the primary human process in the transformation of the environment, dominated the discipline of environmental history. ${ }^{24}$ Historians such as William Cronon, Martin Melosi, Christine Rosen, and Joel Tarr, who were interested in environmental histories of cities, argued that environmental historians had not given enough recognition to the city, both as an environmentally transformative process and as a field of study within the discipline of environmental history. Consequently, the field of urban environmental history emerged as a body of knowledge to study the city as an ecological process. While the field of urban environmental history has matured since then to produce a significant body of work, the field of architectural environmental history has yet to realize its full potential. ${ }^{25}$ In the following section, I look at ways in which environmental histories can intersect with the architectural history survey.

\section{THE GOALS OF AN ARCHITECTURAL ENVIRONMENTAL HISTORY SURVEY}

A history of architecture survey that is taught within the broader discipline of environmental history can have multiple objectives that can engage sustainability's relationship to architecture and urbanism in several ways. These goals can be: one, to historicize environmental problems in relationship to the built environment; two, to understand architecture and cities as ecosystems, in terms of resource cycles such as building materials, fuels, and water; three, to grasp environmental management in the service of architecture and urbanism; and four, to understand how civilizations change under environmental stresses. In the following section, I illustrate how these themes can be included in the architectural history survey and through specific examples I will show how environmental histories can inform architectural histories.

\section{Environmental Problems in Relationship to the Built Environment}

The problems addressed in the Brundtland Report - rising population, food insecurity, loss of ecosystems, diminishing biodiversity, dependence on non-renewable polluting energy sources, inefficient industrial production systems, inefficacious land use for agriculture and urbanization, and deteriorating commons, have precedents in human history. John McNeill in Something New Under the Sun notes that with a few exceptions, like the thinning of the Ozone layer, most environmental problems of the twentieth century are not new. However, they are unprecedented in their scope, acuteness, and scale. ${ }^{26}$ For the first time in history, the extent of human induced environmental transformations matches the magnitude of naturally generated environmental changes. ${ }^{27}$ An environmental architectural history survey can illuminate how architecture and cities have contributed to environmental stresses in the past and the transformation of societies under those environmental stresses.

Let's consider Roman aqueducts, which are regarded as marvels of Roman hydraulic engineering. The architecture of water collection, storage, and distribution is useful in examining water consumption and its impact on water sources. The pollution of the Tiber due to waste discharge necessitated the construction of such aqueducts. ${ }^{28}$ The aqueducts are celebrated in architectural history as a prime example of arcuated construction and how they made the Roman leisure culture of baths possible. However, the Roman aqueduct and water distribution system incurred high environmental costs due to the consumption of large amounts of water - 350,000,000 gallons per day. ${ }^{29}$ This impacted the 
ecosystems of the places from which the water was drawn; creating a deficit at the source that left the local vegetation and animal life with an inadequate supply. ${ }^{30}$ The case of imperial Rome's water consumption can offer insights into the ecological costs of creating an enormous infrastructure to facilitate the indiscriminate consumption of a finite natural resource such as water.

\section{Architecture and Cities as Ecosystems}

The analysis of the flow of natural resources and energy-building materials, fuels, and water - opens up questions for examining architecture and cities as ecosystems. By adding knowledge of the life cycle analysis of natural resources historically, the surveys can be closely aligned to contemporary discourses on sustainability where architecture and cities are viewed in terms of resource and energy flows. The architectural surveys are fairly comprehensive in addressing the use of building materials in construction. In order to focus on the flow of building materials as part of an ecosystem, enquiries such as how the building materials were acquired, the environmental impact of extracting them, the social group that extracted them, the rate of consumption of those building materials, and the afterlife of building materials can establish architecture in terms of ecological relationships with the environment.

Take the case of Greece. Architectural histories illuminate the relationship between architectural form and the transition from timber to a combination of timber and stone in Greek temple architecture. The evolution of the temple form is a narrative of progress with an ascending trajectory that begins with the megaron and culminates with the Parthenon. It is possible that the Greeks started using stone because their forests became depleted and timber became scarce. By speculating on the environmental reasons for this transition, that is deforestation, the environmental stresses due to building construction can be brought into the fold of architectural history. The impact of the Greek consumption of timber and its environmental consequences in terms of diminishing timber resources, deforestation, soil erosion, and the subsequent introduction of malaria can establish how architectural consumption of natural resources altered the ecosystem. ${ }^{31}$

The ecological cost of the consumption of energy and building materials in imperial Rome constitutes one of the most effective case studies in the survey. Romans are cast as the greatest engineers of the pre-modern world for their achievements in the sphere of infrastructural projects such as roads, bridges, aqueducts, and sewers. The architectural surveys narrate how the Romans used construction materials such as marble, tufa, travertine, concrete, and bricks in the context of Roman technological achievements. The ecological consequences of the use of these materials relate architectural histories to the ecological histories of the Roman Empire. ${ }^{32}$ The Roman processes of mining and quarrying altered the landscape by creating cavities that eroded the land, which in turn deteriorated the quality of the ground water. ${ }^{33}$ The production of bricks, ceramics, and metals placed further stresses on the environment through the combustion of wood and charcoal. ${ }^{34}$ Environmental historians argue that a loss of an optimal adaptation with the natural environment was one of the reasons for the decline of Rome. The social, political, and ecological impacts of the excessive use of resources beyond the carrying capacity of the city of Rome in the context of the Roman Empire can be thematically related to current environmental themes such as the unsustainable use of fossil fuels and water.

\section{Environmental Management}

As a paradigm of environmental management, sustainability calls for the efficient management of land, water, forests, commons, and human settlements. ${ }^{35}$ Sustainable architecture discourses call for a sustainable use of building materials and a change in material cycles from the cradle to grave to the cradle to cradle model. ${ }^{36}$ The impact of architecture and urbanism on natural resources and the underlying environmental management is, however, marginal to existing architecture history surveys.

Environmental management can potentially be a key theme in understanding not only the environmental stresses generated by building activity, but also how natural resources, especially forests, were regulated by societies to achieve sustainable growth. The mechanisms through which societies managed natural resources in the past can provide us with ways of thinking about sustainable societies and their relationship to the environment.

In the case of medieval architectural and environmental histories, cathedral building dominates architectural history and deforestation is the major theme of environmental histories. As a resource, forests provided fuel, timber for architectural construction and ship building, and land for farming and pastures. Environmental histories chart increases in population, agricultural production, and economic activity as key factors in the shrinking forest cover. ${ }^{37}$ The three key categories of medieval cathedral architecture, which are Carolingian, Romanesque, and Gothic, dominate architectural histories. One of the main themes in the development of Romanesque architecture is the objective to create a nave that is vaulted with stone to eliminate the use of timber. ${ }^{38}$ Fire is the major reason cited for this structural transformation, but it can also be attributed to the rising demand for and short supply of timber. The medieval growth of cities and the rise in building activity make a strong case for examining the pressures exerted on the timber supply chain and the consequent change in forestry practices. 
Two examples - medieval northern France and Venice - are noteworthy cases where forestry histories intersect with architectural and urban histories. They can be used to illustrate the impact of building activity on forestry practices. In medieval northern France the changing woodland management practices caused the shift towards coppicing - a sylviculture practice that entails chopping trees at their trunks to achieve fast growth and regeneration of trees from stumps, as opposed to completely uprooting a tree and planting a new one. ${ }^{39}$ Coppicing is a sustainable practice, which met the rising demands of medieval timber consumption. As a consequence of the pressure on timber supply in northern France, the forest management practices changed from gathering naturally available products to actively managing forests. ${ }^{40}$

Venice's environmental management of its Italian mainland forests and its relationship to Venetian urbanism constitutes an important case study of how cities depend on distant resources. The city, built on the sea, did not exist in isolation. Its mainland possessions, which provided the city with supplies of lumber and firewood, included northeastern Italy, the western half of the Istrian Peninsula, and most of the Dalmatian coast. Venetian buildings were built on tolpi (wooden piles), which constituted load-bearing foundations. The larch, alder, and oak beams that form the primary structural material on which Venetian architecture is founded were sourced from its mainland possessions. ${ }^{41}$ The Venetian Republic actively managed their forests through what Karl Appuhn calls "managerial organicism," a paradigm of environmental management based on conservation through a prioritized selective use of forests. ${ }^{42}$ Managerial organicism relied heavily on knowledge generated through aggressive mapping and surveying.

Venetian environmental management included not only early modern forest management on the Italian mainland, but also the rigorous regulation of water in the city to maintain the delicate balance between the ocean and the lagoon. The present-day problems related to the sinking of Venice that include rise of sea levels, sinking buildings, and decaying infrastructure can be historicized in relationship to the building of Venice and its environmental management. ${ }^{43}$

\section{Civilizations Under Environmental Stresses}

The unsustainability of our lifestyles is not an unprecedented problem. Environmental stresses have been attributed as causal agents in the change of civilizations such as the Roman, the Mayan, and the Indus Valley. The environmental adaptation capabilities of civilizations that went through extreme stresses offers an opportunity to examine what makes societies sustainable and how societies cope with environmental stresses.
Historians contend that the fragmentation of the Western Roman Empire might have been partly due to unsustainable social structures and lifestyles involving excessive inequitable consumption of natural resources. ${ }^{44}$ Such histories can open up room for drawing parallels between the Roman Empire and our present-day attitudes toward inequitable social structures and consuming natural resources. ${ }^{45} \mathrm{~J}$. Donald Hughes argues that the Roman social stratification concentrated wealth and land in the possession of a few powerful people in the society. ${ }^{46}$ This unequal distribution of resources, the unchecked depletion of natural resources, and the practice of slavery contributed to environmental stresses. Hughes makes a compelling argument that environmental factors led to the deterioration of the quality of life in the Roman Empire and hence to its fragmentation. ${ }^{47}$ While a centralized top-down society makes it possible to construct large-scale architectural and infrastructural projects, as the Romans did, according to Hughes such a social structure is ultimately unsustainable as the slaves had no interest in caring for the land they worked on. The Roman example raises questions such as what kind of societal structures are sustainable and why social justice issues are also often environmental issues. Hughes' argument in the case of Rome can be weighed in the context of the causal relationship between poverty and environmental degradation as postulated by the Brundtland Report.

For another example of environmental stresses, the case of Mayan cities, specifically Tikal, and water management offers an interesting. Mayan cities depended on seasonal rainfall cycles to sustain agriculture and urban life. Architectural histories are rich in their emphasis on Tikal's urbanism in relationship to the Mayan cosmic geography. The role of water collection in the city layout can enrich the study of the relationship between water infrastructure and urbanism. Tikal's urban spatial layout in terms of its plaza, pyramids, and platforms was designed to collect rainwater for storage in reservoirs for consumption during the dry months. ${ }^{48}$ The Maya routinely utilized the topography of the site in city building to engineer hydraulic gradients in the distribution of water. Mayanists speculate that the Mayan population grew exponentially during the classic Maya period, reaching close to the carrying capacity of the region, placing excessive stress on the environment. The population pressure and successive droughts may have depleted water reserves. ${ }^{49}$ One of the reasons for the Mayan collapse might have been the centralized control of water reservoirs by Mayan rulers. ${ }^{50}$ Multiyear droughts could certainly have played a role in deflating the authority of the rulers due to water conflicts, creating social unrest. The centralized control of water can also illuminate the relationships between resource management and unsustainable societal structures. The study of water management and its societal impact can be used to raise fundamental questions such as why it is important to have an equitable distribution of resources like energy and water. 
As we run the risk of water scarcity in the coming decades with retreating glaciers, drying rivers, and polluted springs, water management has become an integral part of sustainable architecture and urbanism. One of the ways in which the history survey can establish a dialogue with the design discourse is to raise relevant questions that address water consumption and management.

The ways environmental histories can intersect with architectural histories to historicize environmental problems in relationship to the built environment - to understand architecture and cities as ecosystems, in terms of resource cycles such as building materials, fuels, and water; to grasp environmental management in the context of history; and to understand how civilizations change under environmental stresses - are merely few ways in which the two histories can establish a dialogue with each other.

\section{CHALLENGES OF TEACHING THE ARCHITECTURAL HISTORY SURVEY WITHIN AN ENVIRONMENTAL HISTORY PARADIGM}

In order to accredit architecture programs, the National Architectural Accrediting Board (NAAB) requires that students be educated to grasp historical traditions and global culture "in terms of their climatic, ecological, technological, socioeconomic, public health, and cultural factors." 51 Architectural and urban traditions have so far constituted tectonic expressions, spatial configurations, and construction technologies. The way societies have used environmental knowledge in the making of architecture and cities can also contribute significantly to the cultural understanding of architecture, by illuminating how environmental knowledge determines architecture and urbanism. An environmental history of architecture would strengthen the survey in meeting $N A A B$ guidelines that require an understanding of architecture in ecological terms.

The most formidable challenge to delivering an architectural history survey through an environmental history paradigm is the fear that such an approach would significantly increased the content of the survey, which is under considerable pressure because of the teaching of global histories. The critical question is whether a deeper investigation of environmental histories will dilute the survey. This paper rests on the premise that teaching the survey from an ecological point of view is a new way of writing, organizing, and teaching the survey, where some of the old paradigms and ways of organizing the survey will have to be abandoned to make way for a fresh environmental approach. Such a survey awaits its authors, and certainly this paper is intended to inaugurate a dialogue concerning the writing of an alternative survey. The key history of architecture survey textbooks - Architecture, from Prehistory to Postmodernity; Buildings across Time: An Introduction to World Architecture; A
History of Architecture: Settings and Rituals; A Global History of Architecture; and World Architecture: A Cross-Cultural History are primarily cultural histories of architecture. In the absence of a text that takes the proposed new approach, it is possible to use any one of the existing books in combination with an environmental history text such as J. Donald Hughes' An Environmental History of the World: Humankind's Changing Role in the Community of Life or Stephen Mosley's The Environment in World History.

As this field evolves, there are several existing challenges of teaching the architectural history survey within the larger discipline of environmental history. The periodization and taxonomies of architectural histories do not always neatly correspond with the organization of environmental histories. Nevertheless, given the limitations of existing scholarship, at several points in the architectural survey it becomes particularly challenging to include existing environmental history texts.

The histories of globalization are treated very differently in the two fields. The global history of the environment is defined in ecological terms, while the global histories of architecture are based on the cultural histories of globalization. The project of creating global histories has raised interesting questions in the disciplines of architectural and environmental histories. The term "global" in the architectural history survey is related to globalization as a cultural and political project tied to the flow of ideas, people, styles, tastes, and capital across political borders. ${ }^{52}$ The practice of writing the global survey in architectural history calls for including marginalized world regions that in earlier histories were cast through a Euro-centric lens. In the field of environmental history the project of creating a world history necessitates the task of examining human pasts in the context of the transformations of earth systems. ${ }^{53}$ The biggest challenge to the project of writing global environmental architectural histories will be to combine cultural and ecological histories of globalization.

Although both architectural and environmental histories are bound by place, the definition of what constitutes a place, as a unit of analysis, does not neatly coincide in the two fields. In the architectural history survey, the definition of a "place" as an entity of investigation is determined by competing and shifting parameters, such as political borders (empires, monarchial states, city-states, nation-states), cultural regions, architectural movements (Renaissance, Baroque, Art Nouveau), and the work of individual architects (Palladio's Vicenza, Gaudi's Barcelona, South Asia in the context of Le Corbusier and Kahn). The construct of places in environmental history, by contrast, is beginning to depart from politically and culturally defined regions to places defined by ecological actors. ${ }^{54}$ Architectural and urban histories 
engage with place-making as a cultural project with marginal emphasis on the role of the environment in place-making. The cultural production, consumption, reception, and circulation of the architectural object are central to the architectural survey. From the disciplinary perspective of environmental history, it is important to understand architecture and cities as ecological processes.

Consider the cases of early river valley civilizations such as Egypt along the Nile, the Mesopotamian civilization along the Tigris and Euphrates, the Indus Valley civilization, and the Chinese civilization on the Yellow River. In regard to these river valley civilizations, the definition of a region is somewhat synergetic in architectural and environmental histories. Yet the architecture of South Asia in the survey is structured on the basis of colonial historiography whereby architecture is grasped through the taxonomies of "Buddhist," "Hindu," and "Islamic.."55 In order to teach this history from an environmental perspective, it would be more useful to refer to histories that are ecologically place-bound. For example, it would be better if the history of the cities and architecture all along the Ganges could be taught in relationship to the hydraulic regime of the river. The cultural histories of architecture and urbanism with respect to the ecological histories of the Ganges are yet to be written. ${ }^{56}$

\section{CONCLUSION}

Through the architectural survey we might be able to create a curriculum that includes ecological and cultural histories of architecture and cities. Including themes such as the anthropogenic transformation of the environment, the impact of architecture and urbanism on the environment, the environmental transformation of civilizations, and the history of environmentalism can enrich the architectural survey by establishing various methods through which the relationship between architecture and sustainability can be examined. These areas of knowledge have traditionally been the territory of environmental historians.

One would think that there would be a natural and seamless synergy between architectural and environmental history surveys. However, there are several disciplinary gaps of knowledge between architectural and environmental histories. This necessitates the production of new architectural histories that are refracted through an environmental lens. These new histories and the architectural environmental survey, yet to be written, would occupy the interdisciplinary intersection of environmental and architectural histories.

There are many challenges to producing a revisionist environmental history survey of architecture. Environmental history is an emerging field. There is not enough scholarship on the period before the nineteenth and twentieth centuries that can be related to histories of architecture and urbanism. There are not enough environmental histories from within the discipline of architecture. Writing histories of architecture from an environmental perspective will require drawing upon science, ecology, history of technology, and environmental histories, as well as a different kind of training for architectural historians. It will require collaborations between people trained as architectural historians and environmental historians.

Acknowledgments: I would like to thank my colleagues Victoria Pagan and Hui Zou at the University of Florida for their valuable feedback. I am extremely grateful to Philip Plowright and the anonymous reviewers of this article for their valuable suggestions in revising this paper.

\section{ENDNOTES}

1 The United Nations Conference on Environment and Development (UNCED) - held in Rio de Janeiro, 3-14 June 1992 - is popularly known as the Rio Summit. The conference produced a manifesto tilted "AGENDA 21," which lists six key themes - quality of life on earth, the efficient use of the world's natural resources, the protection and management of our global commons, the atmosphere and the oceans, the management of human settlements, the use of chemicals and the management of human and industrial waste, and global economic growth based on sustainability. See United Nations Conference on Environment and Development and D. Sitarz, Agenda 21: The Earth Summit Strategy to Save Our Planet (Boulder, CO: EarthPress, 1993).

2 World Commission on Environment Development, Our Common Future (Oxford; New York: Oxford University Press, 1987).

3 D. H. Meadows and Club of Rome, The Limits to Growth: A Report for the Club of Rome's Project on the Predicament of Mankind (New York: Universe Books, 1972); E. F. Schumacher, Small Is Beautiful: Economics as If People Mattered (New York: Harper \& Row, 1973).

$4 \quad$ UNCED and Sitarz, Agenda 21.

5 See Academic Programs in Sustainability on AASHE's (Association for Advancement of Sustainability in Higher Education) website: http://www.aashe.org/resources/academic-programssustainability

6 B. G. Norton, Sustainability: A Philosophy of Adaptive Ecosystem Management (Chicago: University of Chicago Press, 2005).

7 In the discipline of engineering, see J. R. Mihelcic et al., "Sustainability Science and Engineering: The Emergence of a New Metadiscipline." Environmental Science \& Technology, 37, 23 (2003), pp. 5314-5324.

$8 \quad$ M. Jarzombek, "Molecules, Money and Design: The Question of Sustainability's Role in Architectural Academe." Thresholds, 18, Design \& Money (Spring 1999), pp. 32-38.
P. Tabb and A. S. Deviren, The Greening of Architecture: A Critical History and Survey of Contemporary Sustainable Architecture 
and Urban Design (Burlington, VT: Ashgate, 2013).

10 See P. Anker, "The Closed World of Ecological Architecture," The Journal of Architecture, 10, 5 (2005), pp. 527-552; W. McDonough and M. Braungart, Cradle to Cradle: Remaking the Way We Make Things (New York: North Point Press, 2002); V. Olgyay and J. Herdt, "The Application of Ecosystems Services Criteria for Green Building Assessment," Solar Energy, 77, 4 (2004), pp. 389398; D. W. Orr, The Nature of Design: Ecology, Culture, and Human Intention (New York; Oxford: Oxford University Press, 2004); Tabb and Deviren, The Greening of Architecture; N. Todd and J. Todd, From Eco-Cities to Living Machines: Principles of Ecological Design (Berkeley, CA: North Atlantic Books, 1994); U.S. Green Building Council, LEED Green Building Rating Systems (Annapolis, MD: Office of the Secretary of State, Div. of State Documents, 2006); S. Van der Ryn and S. Cowan, Ecological Design (Washington, DC: Island Press, 1995).

11 Olgyay and Herdt, "The Application of Ecosystems Services Criteria for Green Building Assessment," pp. 389-398.

12 A. G. Kwok and W. T. Grondzik, The Green Studio Handbook: Environmental Strategies for Schematic Design (Oxford: Architectural Press, 2007), pp. 1-6.

13 S. Guy and G. Farmer, "Reinterpreting Sustainable Architecture: The Place of Technology." Journal of Architectural Education, 54, 3 (2001), pp. 140-148.

14 For recent scholarship that analyzes design discourses in terms of the cultural and ethical aspects of sustainability, see M. Jarzombek, "Sustainability, Architecture, and 'Nature' Between Fuzzy Systems and Wicked Problems." Thresholds, 26, Denatured (Spring 2003), pp. 54-56; Orr, The Nature of Design; K.Tanzer and R. Longoria, eds., The Green Braid: Towards an Architecture of Ecology, Economy, and Equity (London; New York: Routledge, 2007).

15 S. Mosley, The Environment in World History (Abingdon, UK; New York: Routledge, 2010), pp. 1-13.

16 J. D. Hughes, An Environmental History of the World: Humankind's Changing Role in the Community of Life (Abingdon, UK; New York: Routledge, 2009), p. 4.

17 R. White, "Environmental History, Ecology, and Meaning." The Journal of American History, 76, 4 (1990), pp. 1111-1116. J. R. McNeill, "Observations on the Nature and Culture of Environmental History." History and Theory, 42, 4 (2003), pp. 5-43. Hughes, An Environmental History of the World, pp. 30-51.

F. Ching, M. Jarzombek, and V. Prakash, A Global History of Architecture (Hoboken, NJ: J. Wiley \& Sons, 2007); R. Ingersoll and S. Kostof, World Architecture: A Cross-Cultural History (New York: Oxford University Press, 2013); S. Kostof, A History of Architecture: Settings and Rituals (New York: Oxford University Press, 1985); M. Moffett, M. W. Fazio, and L. Wodehouse, Buildings across Time: An Introduction to World Architecture (Boston, MA: McGraw-Hill Higher Education, 2009); M. Trachtenberg and I. Hyman, Architecture, from Prehistory to Postmodernity (New York: Harry N. Abrams, 2002).

Mosley, The Environment in World History, pp. 1-13.

22 P. Anker, From Bauhaus to Ecohouse: A History of Ecological Design (Baton Rouge: Louisiana State University Press, 2010); M. Murphy, Sick Building Syndrome and the Problem of Uncertain- ty: Environmental Politics, Technoscience, and Women Workers (Durham, NC: Duke University Press, 2006); D. Orr, Design on the Edge: The Making of a High-Performance Building (Cambridge, Mass.: MIT Press, 2006); Tabb and Deviren, The Greening of Architecture. See also P. Anker, "Science in Culture: Bauhaus at the Zoo." Nature, 439, 7079 (2006), p. 916; R. Banham, The Architecture of the Well-Tempered Environment (London; Chicago: Architectural Press; University of Chicago, 1973); A. Kirk, "Appropriating Technology: The Whole Earth Catalog and Counterculture Environmental Politics." Environmental History, 6, 3 (2001), pp. 374-394; S. Mosley, "Fresh Air and Foul: The Role of the Open Fireplace in Ventilating the British Home, 1837-1910." Planning Perspectives, 18, 1 (2003), pp. 1-21; A. W. Rome, "From the Solar Home to the All-Electric Home," in The Bulldozer in the Countryside, Suburban Sprawl and the Rise of American Environmentalism (Cambridge; New York: Cambridge University Press, 2001), pp. 45-86; S. Sadler, "Drop City Revisited." Journal of Architectural Education, 59, 3 (2006), pp. 5-14; Sadler, "An Architecture of the Whole." Journal of Architectural Education, 61, 4 (2008) pp. 108-129; F. D. E. Scott, "Revolutionaries or Drop Outs," in Architecture or Techno-Utopia: Politics after Modernism (Cambridge, MA: MIT Press, 2007), pp. 151-184.

23 See M. Gandy, Concrete and Clay: Reworking Nature in New York City (Cambridge, MA: MIT Press, 2002).

24 C. M. Rosen and J. A. Tarr, "The Importance of an Urban Perspective in Environmental History." Journal of Urban History, 20, 3 (May 1994), pp. 299-310.

25 See Joel Tarr's historiographic essay on urban environmental history: J. A. Tarr, "Urban History and Environmental History in the United States: Complementary and Overlapping Fields," in C. Bernhardt, ed., Environmental Problems in European Cities in the 19th and 20th Century (Munster; New York: Waxmann, 2004), pp. $25-40$.

26 J. R. McNeill, Something New Under the Sun: An Environmental History of the Twentieth-Century World (New York: W.W. Norton \& Co., 2000), pp. 3-17.

27 Ibid. McNeill argues that the human induced environmental problems of the past were localized in their impact, which is no longer the case as we deal with global problems, such rising sea levels. In addition, we face the possibility of crossing certain thresholds that consequently unleash a chain of events that progress on a non-linear trajectory, like exceeding the 26 degree Celsius temperature mark in the tropical Atlantic that promotes an increased number of hurricanes of greater intensity.

28 Moffett, Fazio, and Wodehouse, Buildings across Time, pp. 110139.

29 Trachtenberg and Hyman, Architecture, from Prehistory to Postmodernity, p. 125.

30 J. D. Hughes, "Urban Problems," in Pan's Travail: Environmental Problems of the Ancient Greeks and Romans (Baltimore: Johns Hopkins University Press, 1996), pp. 149-168.

31 J. D. Hughes, "The Impact of Greek Civilization on the Natural Environment," in Ecology in Ancient Civilizations (Albuquerque: University of New Mexico Press, 1975), pp. 68-86.

32 J. D. Hughes, "Environmental Impacts of the Roman Economy and Social Structure: Augustus to Diocletian," in A. Hornborg, J. 
R. McNeill, and J. Martínez Alier, eds., Rethinking Environmental History: World-System History and Global Environmental Change (Lanham, MD: AltaMira Press, 2007), pp. 27-40; Hughes, "Urban Problems."

J. D. Hughes, "Industrial Technology and Environmental Damage," in Pan's Travail, pp. 112-129.

Ibid.

UNCED and Sitarz, Agenda 21.

McDonough and Braungart, Cradle to Cradle.

J. O. Kaplan, K. M. Krumhardt and N. Zimmermann, "The prehistoric and preindustrial deforestation of Europe." Quaternary Science Reviews, 28 (2009), pp. 3016-3034.

Moffett, Fazio, and Wodehouse, Buildings across Time, pp. 191224.

R. Keyser, "The Transformation of Traditional Woodland Management: Commercial Sylviculture in Medieval Champagne." French Historical Studies, 32, 3 (2009), pp. 353-384.

Ibid.

K. R. Appuhn, A Forest on the Sea: Environmental Expertise in Renaissance Venice (Baltimore, Johns Hopkins University Press, 2009).

Ibid.

C. Fletcher and T. Spencer, Flooding and Environmental Challenges for Venice and Its Lagoon: State of Knowledge (Cambridge; New York: Cambridge University Press, 2005).

Hughes, An Environmental History of the World, p. 74.

lbid.

Hughes, "Environmental Impacts of the Roman Economy and Social Structure"; Hughes, "Urban Problems."

Hughes, "Environmental Impacts of the Roman Economy and Social Structure."

V. L. Scarborough and G. G. Gallopin, "A Water Storage Adaptation in the Maya Lowlands." Science, 251, 4994 (1991), pp. 658662.

G. H. Haug, D. Günther, L. C. Peterson, D. M. Sigman, K. A. Hughen, and B. Aeschlimann, "Climate and the Collapse of Maya Civilization." Science, New Series, 299, 5613 (March 14, 2003), pp. 1731-1735.

lbid.

One of the NAAB's criteria for assessing the architectural history curriculum for educational outcomes is the efficacy of the curriculum in educating students about "Historical Traditions and Global Culture," which requires "An understanding of parallel and divergent canons and traditions of architecture, landscape and urban design including examples of indigenous, vernacular, local, regional, national settings from the Eastern, Western, Northern, and Southern hemispheres." See National Architectural Accrediting Board, Procedures For Accreditation (Washington, DC: National Architectural Accrediting Board, 2013).

Ching, Jarzombek, and Prakash, A Global History of Architecture, xi-xvi.

E. Burke III, "Preface," in E. Burke III and K. Pomeranz, eds., The Environment and World History (Berkeley: University of California Press, 2009), pp. xi-xiv.

Ibid., pp. 3-32.

T. R. Metcalf, An Imperial Vision: Indian Architecture and Britain's
Raj (Berkeley: University of California Press, 1989), pp. 24-54.

56 See environmental history books that have been written from the perspective of the human transformation of rivers in the context of nineteenth century engineering, for example: M. Cioc, The Rhine: An Eco-Biography, 1815-2000 (Seattle: University of Washington Press, 2002); D. H. Porter, The Thames Embankment : Environment, Technology, and Society in Victorian London (Akron, $\mathrm{OH}$ : University of Akron Press, 1998).

\section{REFERENCES}

Anker, Peder. "The Closed World of Ecological Architecture." The Journal of Architecture, 10, 5 (2005), pp. 527-552.

- - "Science in Culture: Bauhaus at the Zoo." Nature, 439, 7079 (2006), p. 916.

- - From Bauhaus to Ecohouse: A History of Ecological Design. Baton Rouge: Louisiana State University Press, 2010.

Appuhn, Karl Richard. A Forest on the Sea: Environmental Expertise in Renaissance Venice. Baltimore: Johns Hopkins University Press, 2009.

Banham, Reyner. The Architecture of the Well-Tempered Environment. London; Chicago: Architectural Press; University of Chicago, 1973.

Burke III, E. "Preface," in E. Burke III and K. Pomeranz, eds., The Environment and World History (Berkeley: University of California Press, 2009), pp. xi-xiv.

Ching, Frank, Mark Jarzombek, and Vikramaditya Prakash. A Global History of Architecture. Hoboken, NJ: J. Wiley \& Sons, 2007.

Cioc, Mark. The Rhine: An Eco-Biography, 1815-2000. Seattle: University of Washington Press, 2002.

Fletcher, Caroline, and T. Spencer. Flooding and Environmental Challenges for Venice and Its Lagoon: State of Knowledge. Cambridge; New York: Cambridge University Press, 2005.

Gandy, Matthew. Concrete and Clay: Reworking Nature in New York City. Cambridge, MA: MIT Press, 2002.

Guy, Simon, and Graham Farmer. "Reinterpreting Sustainable Architecture: The Place of Technology." Journal of Architectural Education, 54, 3 (2001): 140-148.

Haug, Gerald H., Detlef Günther, Larry C. Peterson, Daniel M. Sigman, Konrad A. Hughen, and Beat Aeschlimann. "Climate and the Collapse of Maya Civilization." Science, New Series, 299, 5613 (March 14, 2003), pp. 1731-1735.

Hornborg, Alf, John Robert McNeill, and Juan Martínez Alier, eds. Rethinking Environmental History: World-System History and Global Environmental Change. Lanham, MD: AltaMira Press, 2007.

Hughes, J. Donald. Ecology in Ancient Civilizations. Albuquerque: University of New Mexico Press, 1975.

- - Pan's Travail: Environmental Problems of the Ancient 
Greeks and Romans. Baltimore: Johns Hopkins University Press, 1996.

- - "Environmental Impacts of the Roman Economy and Social Structure: Augustus to Diocletian," in A. Hornborg, J. R. McNeill, and J. Martínez Alier, eds., Rethinking Environmental History: World-System History and Global Environmental Change (Lanham, MD: AltaMira Press, 2007), pp. 27-40.

- - An Environmental History of the World: Humankind's Changing Role in the Community of Life. Abingdon, UK; New York: Routledge, 2009.

Ingersoll, R., and S. Kostof, World Architecture: A Cross-Cultural History. New York: Oxford University Press, 2013.

Jarzombek, Mark. "Molecules, Money and Design: The Question of Sustainability's Role in Architectural Academe." Thresholds, 18, Design \& Money (Spring 1999), pp. 32-38.

- - . "Sustainability, Architecture, and 'Nature' Between Fuzzy Systems and Wicked Problems." Thresholds, 26, Denatured (Spring 2003), pp. 54-56.

Kaplan, Jed O., Kristen M. Krumhardt, and Niklaus Zimmermann. "The Prehistoric and Preindustrial Deforestation of Europe." Quaternary Science Reviews, 28 (2009), pp. 3016-3034.

Keyser, Richard. "The Transformation of Traditional Woodland Management: Commercial Sylviculture in Medieval Champagne." French Historical Studies, 32, 3 (2009), pp. 353-384.

Kirk, Andrew. "Appropriating Technology: The Whole Earth Catalog and Counterculture Environmental Politics." Environmental History, 6, 3 (2001): 374-394.

Kostof, Spiro. A History of Architecture: Settings and Rituals. New York: Oxford University Press, 1985.

Kwok, Alison G., and Walter T. Grondzik. The Green Studio Handbook: Environmental Strategies for Schematic Design. Oxford: Architectural Press, 2007.

McDonough, William, and Michael Braungart. Cradle to Cradle: Remaking the Way We Make Things. New York: North Point Press, 2002.

McNeill, John Robert. Something New Under the Sun: An Environmental History of the Twentieth-Century World. New York: W.W. Norton \& Co., 2000.

- - "Observations on the Nature and Culture of Environmental History." History and Theory, 42, 4 (2003), pp. 5-43.

Meadows, Donella H., and Club of Rome. The Limits to Growth: A Report for the Club of Rome's Project on the Predicament of Mankind. New York: Universe Books, 1972.

Metcalf, Thomas R. An Imperial Vision: Indian Architecture and Britain's Raj. Berkeley: University of California Press, 1989.
Mihelcic J. R., J. C. Crittenden, M. J. Small, D. R. Shonnard, D. R. Hokanson, Q. Zhang, H. Chen, S. A. Sorby. V. U. James, J. W. Sutherland, and J. L. Schnoor. "Sustainability Science and Engineering: The Emergence of a New Metadiscipline." Environmental Science \& Technology, 37, 23 (2003), pp. 5314-5324.

Moffett, Marian, Michael W. Fazio, and Lawrence Wodehouse. Buildings across Time : An Introduction to World Architecture. Boston, MA: McGraw-Hill Higher Education, 2009.

Mosley, Stephen. "Fresh Air and Foul: The Role of the Open Fireplace in Ventilating the British Home, 1837-1910." Planning Perspectives, 18, 1 (2003): 1-21.

- - The Environment in World History. Abingdon, UK; New York: Routledge, 2010.

Murphy, Michelle. Sick Building Syndrome and the Problem of Uncertainty: Environmental Politics, Technoscience, and Women Workers. Durham, NC: Duke University Press, 2006.

National Architectural Accrediting Board. "Procedures for Accreditation." Washington, DC: National Architectural Accrediting Board, 2013.

Norton, Bryan G. Sustainability: A Philosophy of Adaptive Ecosystem Management. Chicago: University of Chicago Press, 2005.

Olgyay, V., and J. Herdt. "The Application of Ecosystems Services Criteria for Green Building Assessment," Solar Energy, 77, 4 (2004): 389-398.

Orr, David W. The Nature of Design: Ecology, Culture, and Human Intention. New York; Oxford: Oxford University Press, 2004.

Orr, David W. Design on the Edge: The Making of a HighPerformance Building. Cambridge, Mass.: MIT Press, 2006.

Porter, Dale H. The Thames Embankment : Environment, Technology, and Society in Victorian London. Akron, $\mathrm{OH}$ : University of Akron Press, 1998.

Rome, Adam Ward. The Bulldozer in the Countryside: Suburban Sprawl and the Rise of American Environmentalism, Studies in Environment and History. Cambridge; New York: Cambridge University Press, 2001.

Rosen, Christine Meisner, and Joel Arthur Tarr. "The Importance of an Urban Perspective in Environmental History." Journal of Urban History, 20, 3 (May 1994), pp. 299310.

Sadler, Simon. "Drop City Revisited." Journal of Architectural Education, 59, 3 (2006), pp. 5-14.

- - "An Architecture of the Whole." Journal of Architectural Education, 61, 4 (2008), pp. 108-129.

Scarborough, Vernon, L., and Gary G. Gallopin. "A Water Storage Adaptation in the Maya Lowlands." Science, 251, 4994 
(1991), pp. 658-662.

Schumacher, E. F. Small Is Beautiful: Economics as If People Mattered. New York: Harper \& Row, 1973.

Scott, Felicity Dale Elliston. Architecture or Techno-Utopia: Politics after Modernism. Cambridge, MA: MIT Press, 2007.

Tabb, Phillip, and A. Senem Deviren. The Greening of Architecture: A Critical History and Survey of Contemporary Sustainable Architecture and Urban Design. Burlington, VT: Ashgate, 2013.

Tanzer, Kim, and Rafael Longoria. The Green Braid: Towards an Architecture of Ecology, Economy, and Equity. London; New York: Routledge, 2007.

Tarr, Joel Arthur. "Urban History and Environmental History in the United States: Complementary and Overlapping Fields," in C. Bernhardt, ed., Environmental Problems in European Cities in the 19th and 20th Century. Munster; New York: Waxmann, 2004, pp. 25-40.

Todd, Nancy Jack, and John Todd. From Eco-Cities to Living Machines: Principles of Ecological Design. Berkeley, CA: North Atlantic Books, 1994.

Trachtenberg, Marvin, and Isabelle Hyman. Architecture, from Prehistory to Postmodernity. New York: Harry N. Abrams, 2002.

United Nations Conference on Environment and Development and Dan Sitarz. Agenda 21: The Earth Summit Strategy to Save Our Planet. Boulder, CO: EarthPress, 1993.

U.S. Green Building Council. LEED Green Building Rating Systems. Annapolis, MD: Office of the Secretary of State, Div. of State Documents, 2006.

Van der Ryn, Sim, and Stuart Cowan. Ecological Design. Washington, DC: Island Press, 1995.

White, Richard. "Environmental History, Ecology, and Meaning." The Journal of American History, 76, 4 (1990): 11111116.

World Commission on Environment Development. Our Common Future, Oxford Paperbacks. Oxford; New York: Oxford University Press, 1987. 